\title{
Evolution of gully erosion in Steppe of Northern Ukraine
}

\author{
V. Tarasov, \\ Candidate of Agricultural Sciences \\ National Scientific Center «Institute of Soil Science and Agrochemistry named after O.N. \\ Sokolovsky»
}

The purpose. To study dynamics and state of evolution of gullens in conditions of Steppe of Northern Ukraine on an instance of Lugansk oblast. Methods. Cartographical with determination of morphometric indexes of different links of hydrographic network by means of SIS techniques, mathematical-statistical and field surveys. Results. Analysis of indexes gully erosion has determined substantial increase of annual increase of gullens for the last 25 years. By results of analysis mathematical model which formalizes process of gullying is created. Conclusions. At saving trend of increase of gullens their firmness will be augmented from 2,6 up to 3,65 units $/ \mathrm{km} 2$, thickness - from 1,59 up to $2,34 \mathrm{~km} / \mathrm{km} 2$. The yielded state requires the further study of the process of gullying and heading of soil-protection measures.

Key words: gullen, hollow, scour, hydrographic network, erosion

Gullying is a main part of an up-to-date relief creating process. It provides a future development of erosion network of the first ranges [1]. Ancient hydrographical network, which comprise river hollows, valleys and coombs is a beginning of new erosion creations (scours and gullies). The most often all ephemeral gullies or scours are begun in runoff concentration places, on the first chains of hydrographical network coombs [2]. At the same time coombs form runoff concentration system on the slope lands and play with this very important function [3]. As they are elements of the ancient hydrographical network, they pretend to comprise ancient gullies under its surface, which were formed in Holocene after regression of Scandinavian glacier [4]. As the coombs surface is covered by plants, erosion processes are not active, but as intensive agricultural cultivation is begun, a complicate erosion and accumulative process is being formed and the first and the second part of that process could be prevailed in dependence of the agricultural loading. From that moment coombs begin to transform itself into gullies or accumulate transported by a runoff soil [5]. Big territories of Ukraine expose to gully erosion. The whole area of 600 thousands of gullies equals to 157 thousands ha [6]. For results of some investigators gully creation on a thalweg of a depression begins, when a rain canal will get the depth of a plough layer [13]. From S.Y. Bulygin data, an eroded soils area in Ukraine every year is being increased on 80 thousands ha, and it does mean, that every year coombs network is being transformed in gullies by 4 thousands km length [7] Damage of the soil on a hydrographical network nowadays takes place through the common use of the short crops rotation with prevailed part of tilled crops. So that gully erosion is the most extreme grade of the soil destruction. Despite of an importance of represented problems, science investigations on gullying condition and development has been done not enough.

Purpose - research of dynamics and conditions of gully development in Northern steppe circumstances of Ukraine on an example of Lugansk region. Determinate the main gully erosion factors and to show their regularity development.

Materials and methods. Object of our investigations was shapes of the line erosion, which were created during the last 25 years. In the base of the investigations was put a cartographical method and some results of field observations. Investigations territory comprises regions of Ukraine north steppe Lugansk region used to belong. For different parts of the region, according to geomorphological characteristics, the length of different chains of a hydrographical network was determined with the help of a key method [8]. 22 keys was selected on a cartographical material to do that. The keys are represented by squares with $100 \mathrm{~km}^{2}$ areas, coincided with coordinates net (fig.1). According to E.M. Mykolayivska method [8] the area of a representative square to don't change relationship between a watershed area and length of hydrographical net slopes on some territory is calculated. The area must be not less than $80 \mathrm{~km}^{2}$. According to this we determined the area of squares in our investigations as $100 \mathrm{~km}^{2}$. On topographic maps with 1:100000 and 1:50000 scales and space prints (Google Earth), in the keys frameworks a length of different chains of hydrographical network was determined. The network included rivers, hollows, coombs, gullies and big scours. The first of all 
on the area of a key in Mapinfo program a vector image of a hydrographical net was constructed to measure the length of its different links. For the main gullies erosion indicators we took the density of gullies (units $\left./ \mathrm{km}^{2}\right)$ and specific length of gullies $\left(\mathrm{km} / \mathrm{km}^{2}\right)[8,9]$.

Investigations results showed, that in 1989 the density of gullies as a whole varied from 0 to 1.32 (units $/ \mathrm{km}^{2}$ ), specific length of gullies - from 0 to $1.04 \mathrm{~km} / \mathrm{km}^{2}$. As is known from much literature origin, in 70-th and 80 -th years of the last century soil conservation complexes the most intensively were introduced [10, 11]. It's because gulling processes did no were intensive. But after reconstruction of the agricultural politic in the 90 -th they did not introduce the system of soil protection measures.

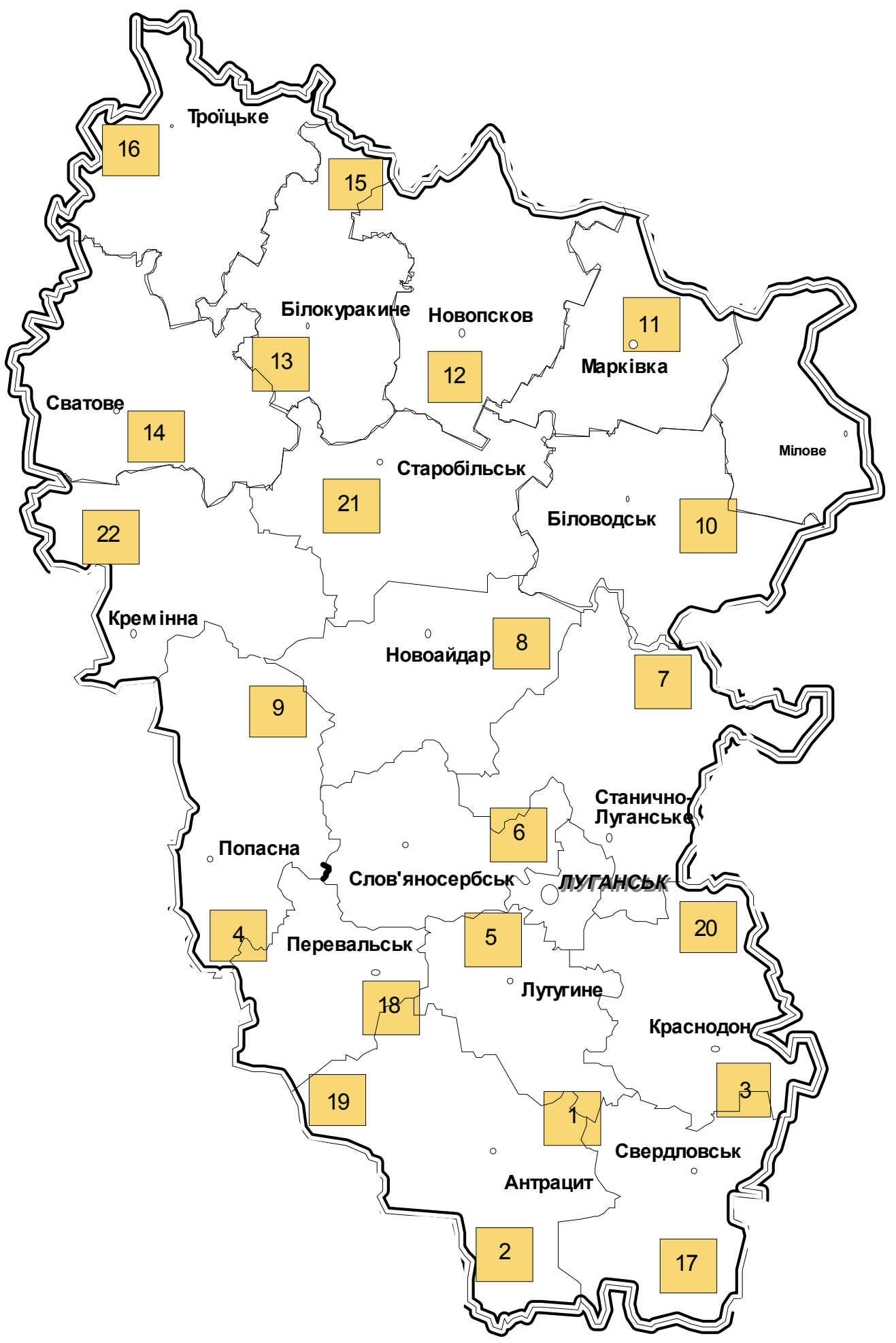

Fig.1 Schema of keys location in the framework of Lugansk region (figures show numbers of the keys) 
As a result, gullying indexes nowadays increased serious. So, for the moment of 2015 year the density of gullies varied from 0.05 to 2.60 units $/ \mathrm{km}^{2}$ and specific length of gullies - from 0.04 до $1.59 \mathrm{~km} / \mathrm{km}^{2}$. The most intensive gullying is observed in the north part of Lugansk region, which is situated on the slopes of the Middle Russian
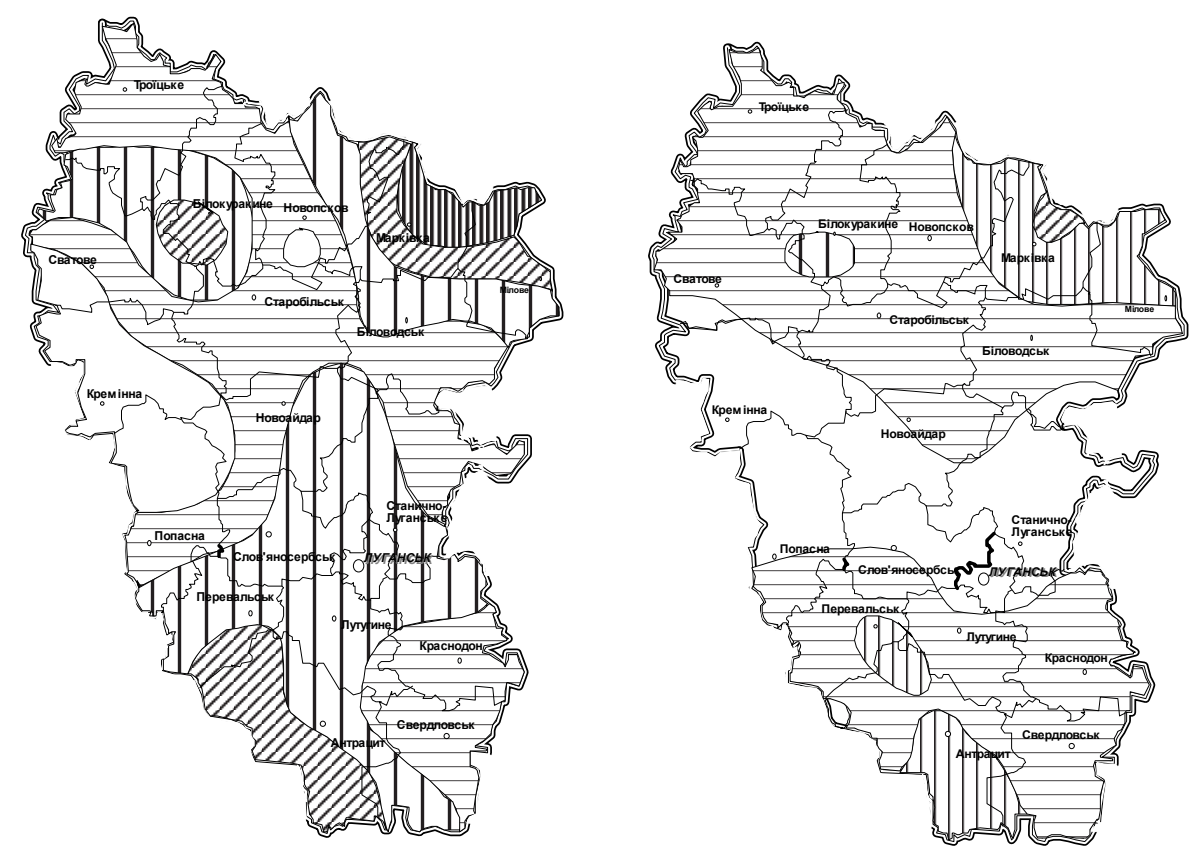

Fig. 2 Cartogram of gullies density, units $/ \mathrm{km}^{2}$ (left) and specific length of gullies, $\mathrm{km} / \mathrm{km}^{2}$ (right) on Lugansk region territory for the moment of 2015 year

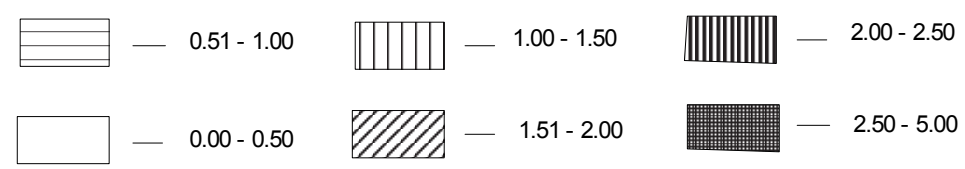

Elevation gully erosion gully erosion (to 2.60 units $/ \mathrm{km}^{2}, 1.59 \mathrm{~km} / \mathrm{km}^{2}$ ) (fig. 2) and on the slopes of Donetsk ridge (to 1.72 . units $/ \mathrm{km}^{2}, 1.40 \mathrm{~km} / \mathrm{km}^{2}$ ).

The most little gullying is observed in Seversk Donets valley, particularly in its east part, where the area is covered by pine forests. Compare analysis of the data showed, that annual increase of gullies length for the last 25 years varied from 0.4 to $25 \mathrm{~m} / \mathrm{km}^{2}\left(20 \mathrm{~m} / \mathrm{km}^{2}\right.$ in Antratsit district and $25 \mathrm{~m} / \mathrm{km}^{2}$ in Markovka district). The first of all such difference is stipulated by local basis of erosion, soils state and economic activity of agricultural farms. Results of the investigations made it possible to carry out multiple-factor analysis and receive a mathematical model of gullying with the next appearance:

$\Delta \mathrm{I}=\left[3.44 . \mathrm{p}^{0.93}\right]\left[0.01 \mathrm{~h}^{0.97}\right] \cdot\left[2.52 \mathrm{e}^{-2.60 \mathrm{f}}\right] \cdot\left[0.075 \mathrm{e}^{0.0048 \mathrm{w}}\right] \cdot\left[0.11 \mathrm{Kec}^{-2.02}\right] ; \quad$ where

$\Delta l$ - yearly increase of gully network for the last 25 years, $\mathrm{km} / \mathrm{km}^{2}$,

$p$ - parameter of gullying, corresponds a relation of the common length of a yang hydrographical net (gullies and big scours) on determined territory to ancient one (rivers valleys, valleys and coombs),

$h$-basis of erosion (difference between the highest and lowest contour lines on a determined territory in meters),

$f$ - Coefficient of gullies afforestation (relation of gullies, covered by forests to gullies without forests),

$w$ - Yearly layer of precipitations, $\mathrm{mm}$,

$K_{e c}-$ Coefficient of ecology stability of the agricultural lands territory, which corresponds a relation of forest and feed crops areas to arable lands [12].

Coefficient of a multiple-factor correlation is equal to $R=0.83 \pm 0.17$;

For the practical use a calculating nomogram was created (fig. 3 ). 
For a determination of a further development of gully erosion it was used a concept of gully erosion potential [1], which does mean highest possible gullying. It includes not only the density and specific length of gullies, but volume of a gully denudation.

Under the conservation of the present gullies dynamics, deep scours could be turned to gullies and on the perspective of the nearest decades characteristics of gully erosion could be serious increased. So, the density of gullies will be increased from 2.6 to 3.65 units $/ \mathrm{km}^{2}$, and specific length from 1.59 to $2.34 \mathrm{~km} / \mathrm{km}^{2}$ (fig. 4).

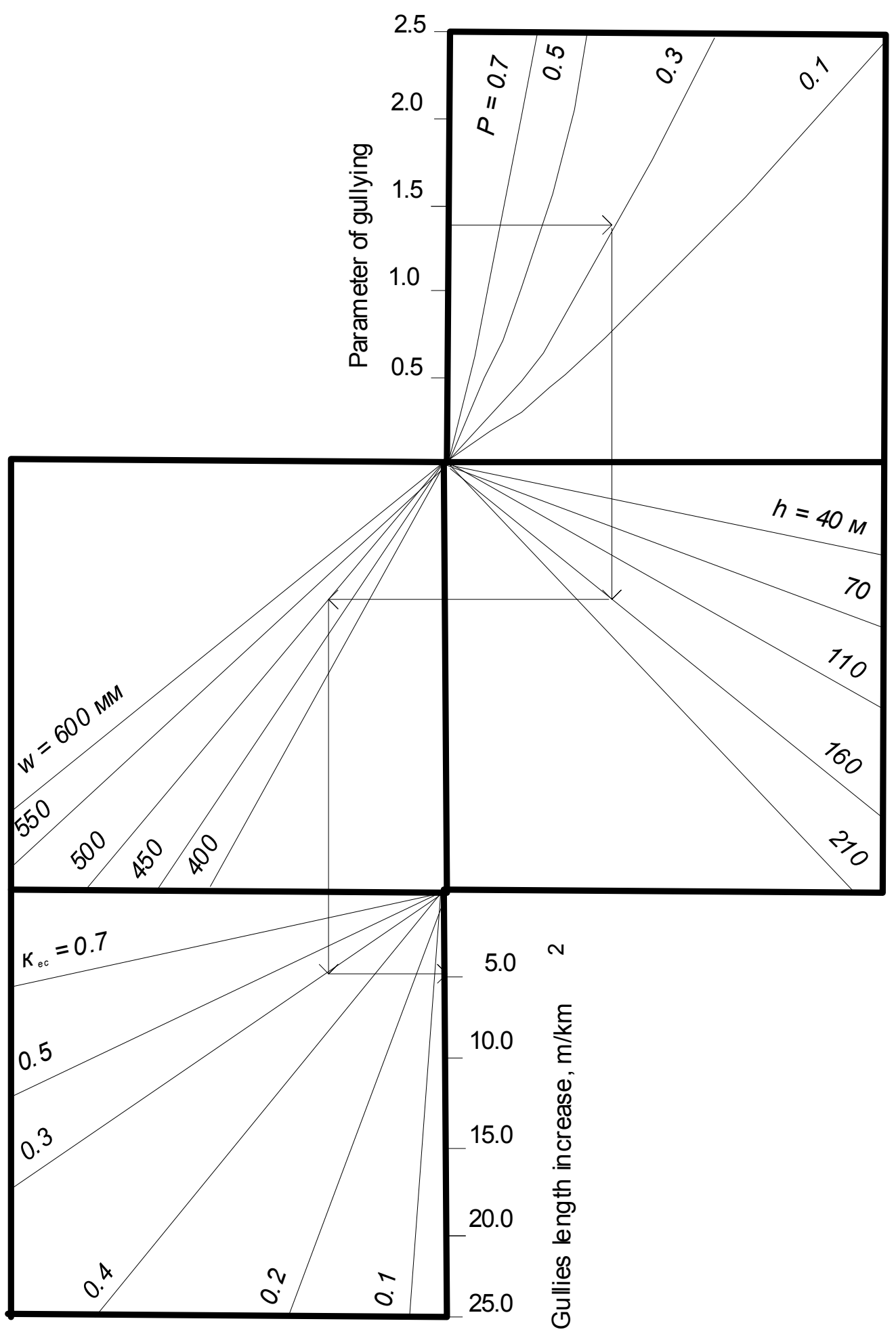

Fig. 3 Calculating nomogram for a determination of the yearly increase of gullies key for calculation 

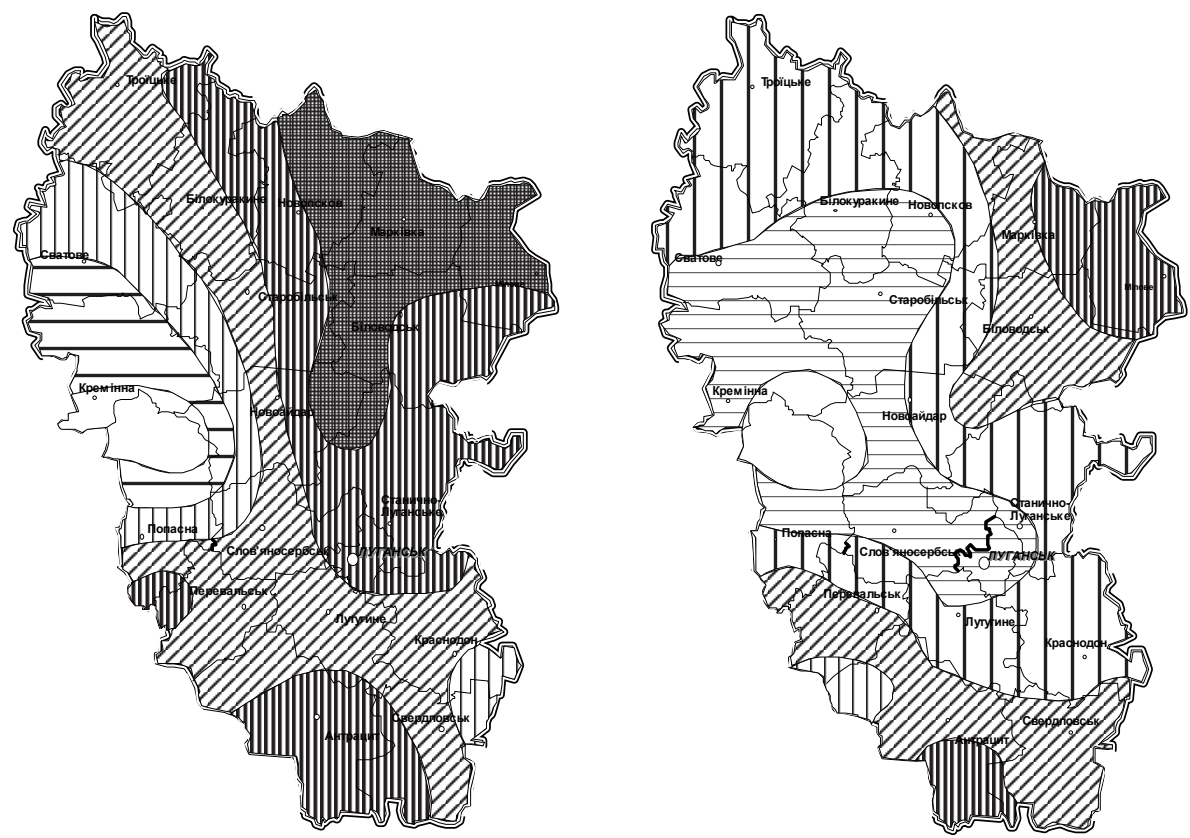

Fig.4 Gullies density potential, units $/ \mathrm{km}^{2}$ (left) and specific length of gullies $\mathrm{km} / \mathrm{km}^{2}$ (right) on Lugansk region territory.
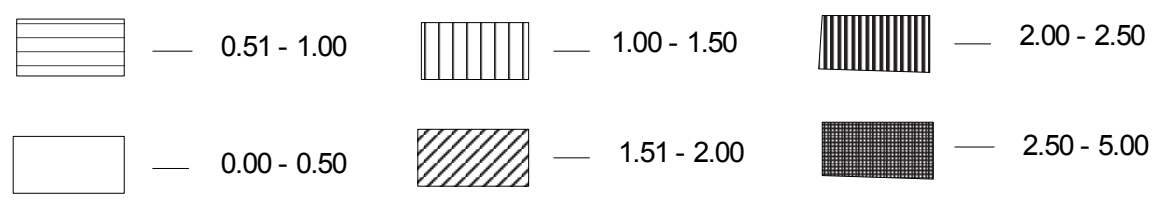

\section{Summary}

Gullying processes in 80-th years of the last century are characterized as moderate ones on the big part of Lugansk region. It was stipulated by intensive introduction of soil conservation complexes on agricultural lands. But for the last years this works were stopped. Therefore the yearly increase of gully length was augmented and in some districts achieved 20.0 and $25.0 \mathrm{~m} / \mathrm{km}^{2}$. Under the conservation of the present gullies dynamics, coombs could be turned to gullies and on the perspective of the nearest decades a highest possible density of gullies will be increased from 2.6 to 3.65 units $/ \mathrm{km}^{2}$, and specific length from 1.59 to 2.34 $\mathrm{km} / \mathrm{km}^{2}$ (fig. 4). Cartograms and mathematical model use will help to optimize composition of different lands on agricultural territories through the coefficient of ecology stability. The situation requires as a further study gullying process and an introduction of soil conservation measures for its stabilization. With them it's necessary to give a preference to vegetation. We consider, that yearly grows of gullies length must be not more $1.0 \mathrm{~km} / \mathrm{km}^{2}$.

\section{Bibliography}

1. Voloschuk M.D. Intensity of gullies grows in the south-west part of Moldavia // Soil erosion and soil protection agriculture._M.: "Kolos", 1975.- P.248-251

2. Roszkov A.G. Struggle with gullies.-M., Kolos, 1981.- 200 p.

3. Kozmenko .A.S. Foundations of the soil control melioration.-M.: "Selkhozgiz", 1954.- 424 p.

4. Sobolev S.S. Erosion processes development on the European part of USSR and measures of the soil control. - M.: Publishing house AS USSR, 1948. - Volume.1.- $260 \mathrm{p}$.

5. Kalinichenko N.P., Zykov I.G. Soil control agro amelioration.- M.: Publishing house Agroprom.- 1986.$279 \mathrm{p}$.

6. Svitlichnyi O., Chernyi S.G. Foundations of torsion: Textbook.- Sumy: VTD «University book», 2007.$266 \mathrm{p}$. 
7. Bulygin S.Y. Forming of ecology stable agrolandscapes. Textbook for preparing of the specialists in agrarian high school of the III - IV levels accreditation.- K.: Urozhay, 2005.- 300 p.

8. Geography of gully erosion. Under the edition of E.F. Zorina.: Publiahing house MSU, 2006 year.- 324 p.

9. Kovalchuk I.P. Erosion processes of East Podol: field, stationary, experiment and morphometrical investigations: Kyiv-Lviv.: liga-Press. 2013.-296 p.

10. Methodics recommendations for the soil control measures complex projects, for territory UCCP / V.A. Dzhamal, N.M. Shelyakin and other. - Voroshilovgrad. - 1982. - 55 p.

11. Tarariko A.G. and other. Main principles of the soil protection contour and reclamation system of agriculture in Forest-steppe zone of Ukraine // Complex of soil control measures in activity. - Voroshilovgrad. - 1985. - Vol. 1 - C.18.

12. Belolipskiy V.A. Prognosis and monitoring of Soil and water protection arrangement of agrolandscapes in Ukraine // Foundations of rational use of nature / Material IV International scientific and practical conference. - Saratov, 2013. - P. 150-157.

13. Lee Gordon, Sean Bennet, Ron Binger and other REGEM : The revised ephemeral gully erosion model // Proceedings of the Eight Federal Interagency Sedimentation Conference (8th FISC), April $2-6$, 2006, Reno, NV, USA. - P. 313 -319. 